\title{
Transcription factor Spo0A switches the localization of the cell division protein FtsZ from a medial to a bipolar pattern in Bacillus subtilis
}

\author{
Petra Anne Levin and Richard Losick ${ }^{1}$ \\ Department of Molecular and Cellular Biology, The Biological Laboratories, Harvard University, Cambridge, Massachusetts \\ 02138 USA
}

\begin{abstract}
Entry into sporulation by the Gram-positive bacterium Bacillus subtilis is governed by two transcription factors, SpoOA and $\sigma^{\mathrm{H}}$, and involves a switch in the site of division from a medial to a polar location. We report that at the onset of sporulation, assembly of the cell division protein FtsZ shifts from midcell to potential division sites near both poles. The switch to a bipolar pattern of FtsZ localization is dependent on Spo0A. Additionally, synthesis of an activated form of SpoOA during growth artificially activates the switch in FtsZ localization and results in the formation of polar septa. The $\sigma^{\mathbf{H}}$ factor, on the other hand, is dispensable for the switch in the position of the FtsZ assembly site, although it is required for formation of the polar septum. Our results suggest that during the transition from growth to sporulation, Spo0A induces the expression of genes that suppress FtsZ assembly at the midcell site and activate sites at both poles, whereas $\sigma^{\mathbf{H}}$ induces genes required for a subsequent step in cytokinesis.
\end{abstract}

[Key Words: Bacillus subtilis; cell division; FtsZ; immunofluorescence microscopy; sporulation; transcription factor]

Received October 16, 1995; revised version accepted December 18, 1995.

Asymmetric division, in which ${ }^{1}$ a progenitor cell gives rise to progeny cells with divergent fates, is a basic theme in development. Unequal divisions in the nematode Caenorhabditis elegans, the green alga Volvox carteri, and the budding yeast Saccharomyces cerevisiae, result in the formation of progeny cells of different sizes and, ultimately, independent destinies (Horvitz and Herskowitz 1992, Kirk et al. 1993|. Similarly, in the Grampositive bacterium Bacillus subtilis, asymmetric division early in the process of sporulation creates two unequal-sized compartments (contained within a common sporangium) with distinct fates (Piggot and Coote 1976; Losick et al. 1986; Errington 1993). The smaller compartment, the forespore, becomes the spore, whereas the larger compartment, the mother cell, participates in the maturation of the spore but eventually lyses to release the spore when development is complete. The means by which $B$. subtilis switches from binary fission during vegetative growth, a process that results in the formation of identical daughter cells with equivalent fates, to asymmetric division at the onset of sporulation is the focus of this paper.

Although little is understood about the mechanisms

'Corresponding author. regulating the site of septum formation, it is known that many of the same genes that are required for vegetative division are also required for asymmetric septation. The products of $f t s A, f t s Z$, and $\operatorname{divIC}$, for example, are essential for division during both growth and sporulation (Beall and Lutkenhaus 1991, 1992; Levin and Losick 1994). This suggests that polar septation may simply be a modified form of vegetative division, with the two septa differing, at least initially, only in position. Additionally, whereas $B$. subtilis does have potential polar division sites present in vegetatively growing cells, they are apparently masked by the products of the $\min C$ and minD genes (Levin et al. 1992; Varley and Stewart 1992; Lee and Price 1993). Mutations in $\min C$ or $\min D$ result in the formation of anucleate minicells located at the cell poles in positions that are similar, if not identical, to that of the forespore compartment. Despite their role in vegetative septum placement, the min gene products are dispensable for sporulation.

Whatever the mechanisms that govern the switch in septal position, several observations indicate that both polar sites are available for asymmetric division, although only one site is chosen in wild-type cells. First, the sporulation septum can be formed at either the pole distal to or proximal to the most recent medial division 
(Hitchin 1975, 1976; Dunn and Mandelstam 1977). Second, mutations that block the appearance of the earliestacting transcription factor $\left(\sigma^{\mathrm{E}}\right)$ in the mother cell result in the formation of disporic sporangia that form, sequentially, two septa located at opposite poles of the same cell (Stragier 1989; Lewis et al. 1994b). Finally, electron micrographs show constrictions in the cell wall that are present at both poles prior to septation and persist at the pole distal to the forespore compartment. It has been suggested that these constrictions are the remnants of division that is initiated simultaneously at both poles but is completed only at one pole (Ryter 1964).

Although no direct regulator of septal position has been identified, two transcription factors that govern entry into sporulation are required for polar septation. These are $\sigma^{\mathrm{H}}$, encoded by the spoOH gene, and SpooA, encoded by spoOA (Losick and Youngman 1984; Stragier 1989|. Mutations in these genes arrest sporulation at stage 0 , prior to asymmetric division. The $\sigma^{\mathrm{H}}$ factor is known to stimulate transcription of the cell division genes $f t s A$ and $f t s Z$ during sporulation, although the $\sigma^{\mathrm{H}}$ controlled promoter of these genes is dispensable for development (Gonzy-Tréboul et al. 1992). The second early-acting transcription factor, SpoOA, is activated by phosphorylation in response to nutritional and cell density signals through the action of a phosphorclay at the onset of sporulation (Grossman 1991; Hoch 1993). Interestingly, when a $\operatorname{spoOA}$ (but not $s p o O H)$ mutant enters sporulation, it produces cells that are approximately half the volume of wild-type sporangia, as if the bacteria continue to divide medially after the onset of sporulation (Dunn et al. 1976). This could indicate that SpoOA directly or indirectly regulates a gene or genes whose products are responsible for the switch in septal position.

To investigate the mechanisms that govern the transition from binary fission to asymmetric division during sporulation, we localized the cell division protein FtsZ in developing cells. FtsZ is an essential cell division protein that has some similarity to tubulin of eukaryotic cells (Erickson 1995). First characterized in Escherichia coli, homologs of FtsZ have been identified in a wide variety of Gram-positive and Gram-negative bacteria, including B. subtilis, Caulobacter crescentus, Rhizobium meliloti, and Streptomyces coelicolor (Yi and Lutkenhaus 1985; Beall et al. 1988; Margolin et al. 1991; McCormick et al. 1994; E. Quardokus, N. Din, and Y.Y. Brun, in prep.). Using antibodies against the cell division protein and immunoelectron microscopy, Lutkenhaus and colleagues discovered that FtsZ polymerizes into a ring at future division sites (Bi and Lutkenhaus 1991; Wang and Lutkenhaus 1993). Because of its distinctive pattern of localization, FtsZ is an excellent marker for the position of nascent septa during development. However, because of its low sensitivity, immunoelectron microscopy could not be used to monitor changes in the localization of Fts $Z$ during vegetative growth and sporulation in $B$. subtilis. We turned instead to immunofluorescence microscopy (IFM) taking advantage of its recent development for use in protein localization in $B$. subtilis (Harry et al. 1995; Pogliano et al. 1995).
Using IFM we demonstrate that the site of FtsZ assembly switches from a medial to a bipolar pattern as cells enter sporulation. This switch in the site of FtsZ localization requires SpoOA, but not $\sigma^{\mathrm{H}}$. Also, synthesis of an activated form of SpoOA during growth was sufficient to switch the pattern of FtsZ localization from medial to polar and to induce the formation of asymmetrically positioned septa, suggesting that SpoOA is responsible for turning on a gene or genes that govern the site of FtsZ polymerization. Finally, we discuss our findings on the localization of FtsZ in vegetatively growing cells of $B$. subtilis as well as in E. coli in light of models for the role of this tubulin-like protein in cytokinesis.

\section{Results \\ Immunolocalization of Fts $Z$ in vegetatively growing cells}

$B$. subtilis grows vegetatively as long chains of septate filaments and does not separate into individual cells until the onset of stationary phase. We used propidium iodide (PI) to visualize septa in growing cells /see Materials and methods]. Because the PI reacts with both DNA and RNA, it stains the entire cytoplasm of the cells, allowing the septa to be seen as dark, unstained bands between brightly stained cellular compartments. PI staining for septa in combination with DAPI staining for DNA revealed that each compartment along a chain of growing cells contained two, closely positioned nucleoids (Fig. 1).

As shown in Figure 2, immunofluorescence allowed us to visualize the pattern of FtsZ localization with relatively high efficiency, almost every cell exhibiting a clcar signal in the form of a band of fluorescence across the short axis of the cells, centered between the pairs of closely positioned nucleoids (Fig. 2, part I, A-C). Additionally, small quaritities of FtsZ could be detected between cells that had completed division (Fig. 2, part I, C). The high frequency of FtsZ rings in vegetatively growing cells was unexpected, a point to which we return in the Discussion.

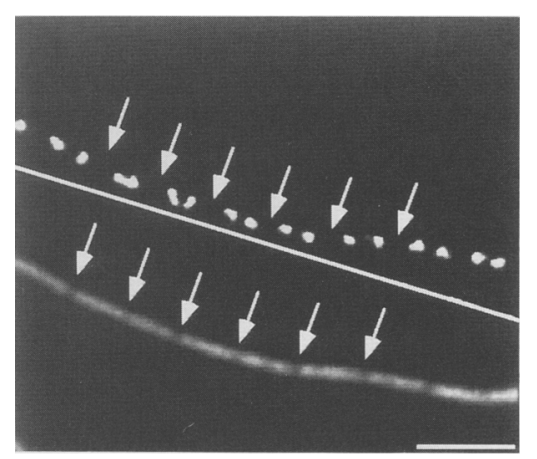

Figure 1. A chain of growing cells stained for nucleoids with DAPI (top) and for septa with PI (bottom). Arrows indicate the positions of the septa located adjacent to the pairs of closely spaced nucleoids. The cells are the wild-type strain PY79. Bar, 5 $\mu \mathrm{m}$. 
Fts Z localizes in a bipolar manner in sporulating cells

In contrast to the medially sited septa of vegetatively growing cells, the septa of sporulating cells are formed close to the poles. The stage of sporulation, and thus the state of septation, can be determined from the pattern of nucleoid staining (Setlow et al. 1991; Lewis et al. 1994a,b; Harry et al. 1995). The earliest stage (stage 0) is

\section{I}
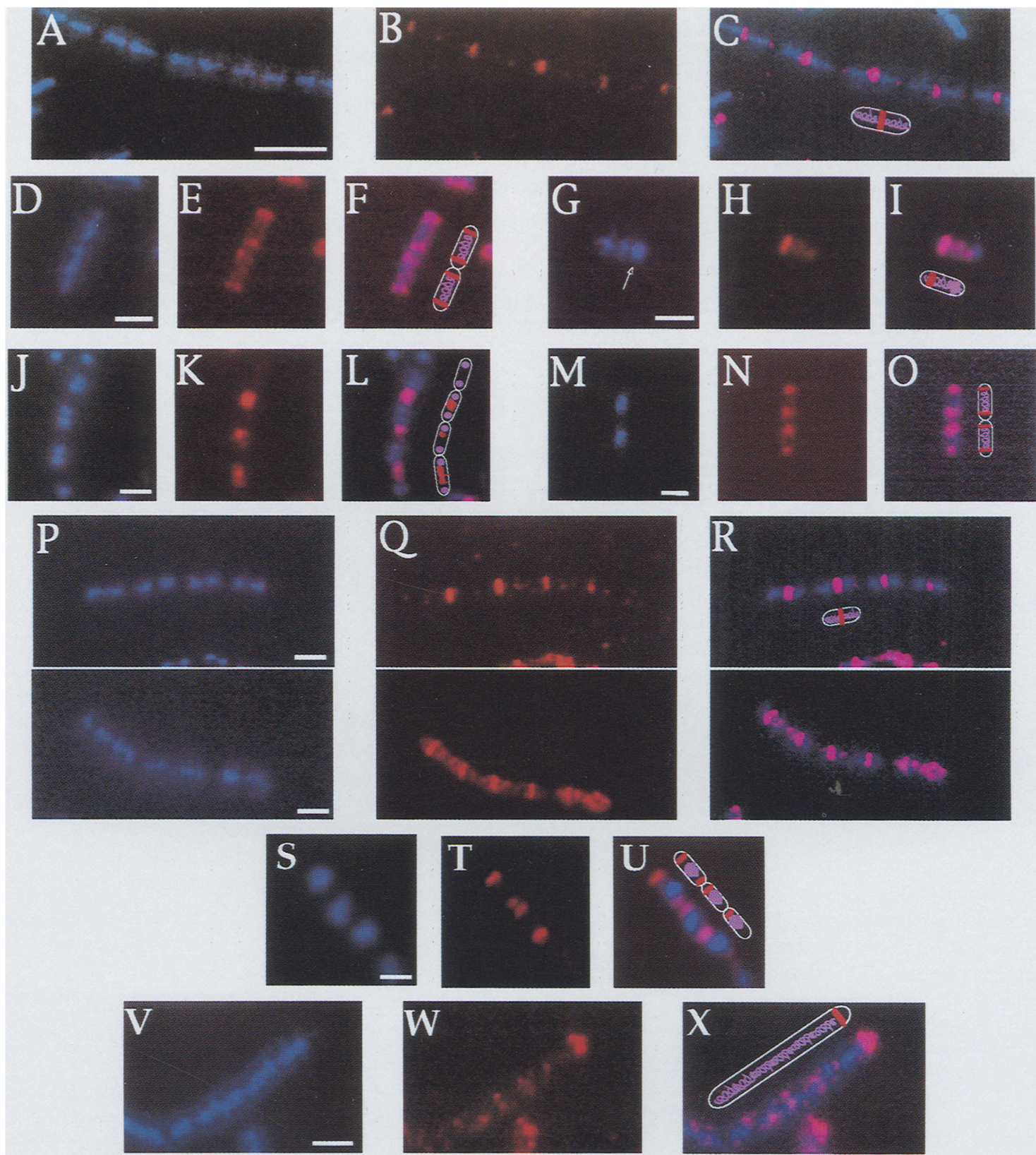

II
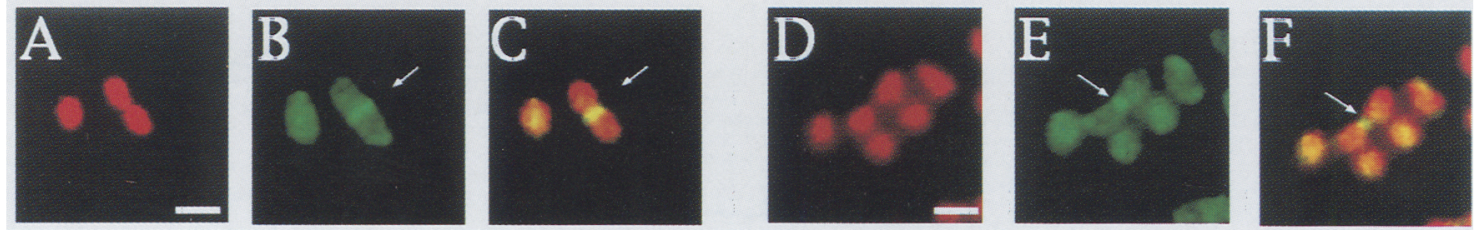

Figure 2. (See facing page for legend) 
characterized by slightly rounded nucleoids (Fig. 2, part I, P). Next, at stage I, the nucleoids form a single, elongate mass known as the axial filament (Fig. 2, part I, D). Finally, at stage II, when the sporangium has undergone septation, the forespore nucleoid can be seen as a brightly staining, highly condensed body, and the mother cell nucleoid is diffuse and slightly elongate (Fig. 2, part I, G). At this stage the activity of $\sigma^{\mathrm{F}}$, the earliestacting transcription factor in the forespore, can be visualized by IFM using antibodies directed against the $\beta$-galactosidase product of a $\sigma^{F}$-controlled lacZ gene fusion (Harry et al. 1995).

In wild-type sporulating cells, just prior to the time of asymmetric septation (stage I), FtsZ was found to be localized near the cell poles, at the ends of the axial filaments (Fig. 2, part I, D-I). Among cells at the axial filament stage of development that exibited this polar pattern of localization, none were detected that additionally displayed medial staining. Thus, cells either exhibited a medial or a polar pattern of FtsZ localization but never both. Early in sporulation the majority of cells had FtsZ localized at both cellular poles (Figs. 2, part I, D-F and 3). However, as sporulation progressed, FtsZ came to be localized principally at a single pole (Figs. 2, part I, G-I, and 3). Finally, at later stages of development, when $\sigma^{\mathrm{F}}$. directed gene expression had commenced, as judged by the accumulation of $\beta$-galactosidase from a $l a c Z$ reporter gene fusion in the forespore (Harry et al. 1995), no distinct pattern of staining was observed and the majority of cells did not stain detectably for FtsZ (data not shown).

The results of DAPI staining indicated that the cells that exhibited a bipolar pattern of FtsZ localization were almost exclusively at the axial filament stage of development (Fig. 4). In addition, $86 \%$ of cells exhibiting a monopolar pattern of localization were also at stage I as determined by the presence of an axial filament. We presume that in such sporangia, FtsZ has depolymerized from the pole at which the sporulation septum has formed but that the nucleoid has not been fully translocated into the forespore compartment (Wu et al. 1995). The remaining $14 \%$ of cells in which localization was restricted to a single pole had a condensed forespore nucleoid located at one pole of the cell, indicating that they were at stage II (Fig. 4). Among these stage II sporangia, FtsZ was localized almost exclusively to the pole opposite the forespore nucleoid (Fig. 2, part I, G-I).

\section{Localization of Fts $Z$ in disporic mutants}

Wild-type sporulating cells normally form a single polar septum. However, sporulating cells of certain disporic mutants undergo division at both poles, producing a three-chambered sporangium with two terminal forespores (Stragier 1989; Lewis et al. 1994b). In disporic mutants, the chromosome that would normally be in the mother cell is segregated into the second polar compartment, leaving the middle compartment between the two forespores anucleate. We examined the pattern of FtsZ localization in the disporic mutant spoIIGB::erm and found that it followed that of wild-type sporangia up until formation of the second septum. Interestingly, disporic sporangia that had reached the stage of complete chromosome segregation to both polar compartments often contained Fts $Z$ localized as a diffuse mass in the middle compartment of the sporangia, somewhere between the two condensed forespore nucleoids (Fig. 2, part I, J-L).

Figure 2. Immunolocalization of FtsZ protein in B. subtillus and E. coli cells. All scale bars are $2 \mu \mathrm{m}$, except where noted. $(I)$ Immunolocalization of FtsZ protein in vegetatively growing and sporulating $B$. subtilis cells. The photographs are of cells stained for nucleoids with DAPI (blue) and immunostained with affinity-purified antibody against the $B$. subtilis FtsZ protein and a secondary antibody conjugated to the red fluorophore $\mathrm{Cy}-3$ (which appears pink in some panels). Each set of photos consists of three different exposures: (1) a DAPI exposure $(A, D, G, J, M, P, S, V) ;(2) \mathrm{Cy}-3$ alone $(B, E, H, K, N, Q, T, W)$; and $(3)$ a multiple exposure in which the relative positions of the FtsZ protein and the nucleoids are simultaneously visible $(C, F, I, L, O, R, U, X)$. Some panels include a cartoon as a schematic representation of what was visualized by immunofluorescence. In these cartoons the perimeter of the cell (not visible in the micrograph) is white, the nucleoid is purple, and the FtsZ protein is red. $(A-C) \mathrm{A}$ chain of vegetatively growing cells (PY79). Note the bands of FtsZ localized between pairs of closely positioned nucleoids in C. Bar, $5 \mu \mathrm{m}$. $(D-F)$ Wild-type cells (PY79) 90 min after the onset of sporulation. The axial filaments formed by the nucleoids are visible in $D$ as is the bipolar localization of the Fts $Z$ protein in $E$ and $F$. (G-I) A second pair of wild-type cells $120 \mathrm{~min}$ after the onset of sporulation that appear to have progressed further in development than the pair in $D-F$. The arrow in $G$ points to the condensed nucleoid in the forespore compartment. FtsZ staining remains only at the pole distal to the condensed nucleoid. $(J-L)$ FtsZ localization in a mature disporic mutant sporangia (RL1061). The remaining Fts $Z$ is concentrated in the center region of the anucleate middle compartments in three of the four disporic cells in this chain. $(M-O)$ Example of bipolar FtsZ localization in a strain mutant for spoOH (RL56). Although these cells have FtsZ near both poles, they are not capable of undergoing division and remain as nonseptate cells. $(P-R)$ Two examples of FtsZ localization in cells mutant for spoOA (RL891). Note that FtsZ localization in these cells is consistently medial and that the nucleoids remain as relatively distinct pairs within each cell. $(S-U)$ Bipolar pattern of FtsZ localization in vegetatively growing cells following induction of sad67 expression (SIK31). Sad67 is a constitutively active form of Spo0A. $(V-X)$ Localization in a cell that carries null mutations in both spo0A and the cell division protein $\min D$ (PL435). There is a single band of FtsZ at the pole of the cell. (II) FtsZ localization in E. coli cells (TG1) during logarithmic growth. $(A, D) E$. coli cells stained for nucleoids with PI which appears as red under epifluorescence. $(B, E) E$. coli cells immunostained with whole sera directed against $E$. coli FtsZ and a green-fluorescing FITC-conjugated secondary antibody. $(C, F)$ Multiple exposures of PI and FITC showing the relative position of the band of FtsZ and the nucleoids. $(A-C)$ An $E$. coli cell early in division, before invagination of the cell wall and membranes. The band of FtsZ is at its maximal width. (D-F) A cell later in division. The cell has now constricted and the FtsZ band is considerably shorter in length. Arrows indicate bands of FtsZ. 
SpoOA but not $\sigma^{H}$ is required for bipolar

localization of FtsZ

Cells carrying a null mutation in spo0A failed to exhibit a bipolar pattern of FtsZ localization. Instead, the medial pattern of localization observed during vegetative growth persisted many hours after resuspension in sporulation medium (Fig. 2, part I, P-R) and the cells continued to divide through binary fission until they were, by appearance, noticeably smaller than wild-type cells at the beginning of sporulation (data not shown). This result agrees with the earlier findings of Dunn et al. (1976), who showed that certain spo0A mutations caused the formation of cells of half the volume of wild-type sporangia.

In contrast, although null mutations in $\mathrm{spoOH}$ prevent formation of the polar septum, $\sigma^{\mathrm{H}}$ appears to be dispensable for selection of polar sites. In general, $s p o O H$ null mutant cells undergoing sporulation stained less well than did wild-type sporulating cells. This observation is consistent with the possibility that $\mathrm{spoOH}$ mutant cells contain less FtsZ during sporulation because $\sigma^{\mathrm{H}}$ is known to direct supplemental transcription of the $f t s Z$ gene (Gholamhoseinian et al. 1992; Gonzy-Tréboul et al. 1992). Nonetheless, cells exhibiting a clear pattern of staining could easily be detected, and spoOH mutant sporangia displaying a bipolar pattern of FtsZ localization were readily apparent (Fig. 2, part I, M-O). The proportion of spoOH mutant cells exhibiting a bipolar FtsZ staining pattern, as compared with a medial pattern, was similar to that observed in wild-type sporangia (data not shown). The nucleoids in the spoOH mutant remained as axial filaments (albeit slightly shorter ones than were observed in wild-type cells) for $>3 \mathrm{hr}$ following resuspension in sporulation medium.

The observation that $\mathrm{spoOH}$ mutant sporangia have axial filaments but not polar septa indicates that they are blocked at stage I. Traditionally, both spoOA and spoOH mutants have been assigned as being blocked at stage 0 , and no mutants have been assigned a stage I block. In light of our results, spoOH should be considered more properly a stage I gene and, hence in conformity with the nomeclature of Piggot and Coote (1976), should be renamed spoIH.

\section{A constitutively active form of SpoOA is able to induce formation of polar septa during vegetative growth}

Spo0A is normally activated by phosphorylation, which is controlled by a phosphorelay cascade in response to sporulation-inducing environmental signals. Deletions in the amino-terminal region of the protein cause it to become constitutively active even in the absence of phosphorylation (Ireton et al. 1993). Expression of one such mutant, sad67, from an IPTG-inducible $P_{\text {spac }}$ promoter during vegetative growth, was sufficient to switch the site of FtsZ assembly from a medial to a polar pattern (Fig. 2, part I, S-U).

The switch in the pattern of FtsZ localization coin-

\section{Minutes after onset of sporulation}

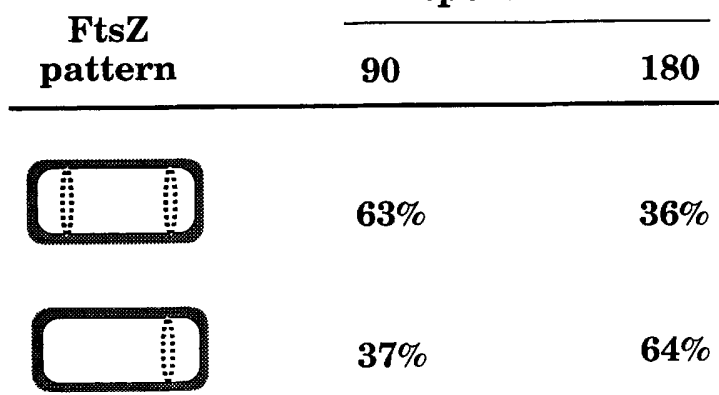

Figure 3. Percentage of sporangia exhibiting either a bipolar or monopolar pattern of FtsZ localization $90 \mathrm{~min}$ and $180 \mathrm{~min}$ after induction of sporulation by resuspension. Three hundred two sporangia (PY79) were scored for the 90-min time point, and 147 sporangia were scored for the $180-\mathrm{min}$ time point. Only cells that exhibited a distinct pattern of FtsZ localization were counted.

cided with the formation of polar septa in cells that normally divide only medially (Fig. 5A,B). These vegetative polar septa were located in roughly the same position, relative to the cell pole, as sporulation septa. In addition, multiple polar septa (up to three in number) were often observed in these cells, situated immediately adjacent to one another at the same pole. Expression of wild-type spo0A from the $P_{\text {spac }}$ promoter during vegetative growth did not result in the formation of polar septa, indicating that phosphorylation of the Spo0A protein is required to activate the switch mechanism (Fig. 5C,D).

Formation of polar septa during vegetative growth in the $P_{\text {spac }}-$ sad67 strain was independent of the presence of $s p O O H$ (data not shown), which suggests that active Spo0A is sufficient to cause a switch in septum location under growth conditions. In contrast, when $P_{\text {spac }}-$ sad67 was induced just prior to the onset of sporulation in nutrient exhaustion medium, the presence of a functional copy of $s p o O H$ was required for polar septation to occur (data not shown). This result supports the argument that although Spo0A $\sim \mathrm{P}$ is sufficient to cause a switch in septal site, the activity of $\sigma^{\mathrm{H}}$ is essential for directing enough expression of the cell division genes to accomplish polar septation during sporulation.

\section{A mutation in minD does not restore bipolar localization of FtsZ to sporulating cells of $a$ spoOA mutant}

One mechanism by which the polar sites could be made available for septation is the inactivation of the $B$. subtilis homologs of the $E$. coli min genes, because mutations in these genes alleviate the division block at the cell poles during growth (Adler et al. 1967; de Boer et al. 1989, 1992; Labie et al. 1990). To determine whether Spo0A was acting through the Min proteins, we constructed a $\operatorname{spo0A} \min D$ double mutant. Had the bipolar localization of FtsZ been dependent on the relief of Min 


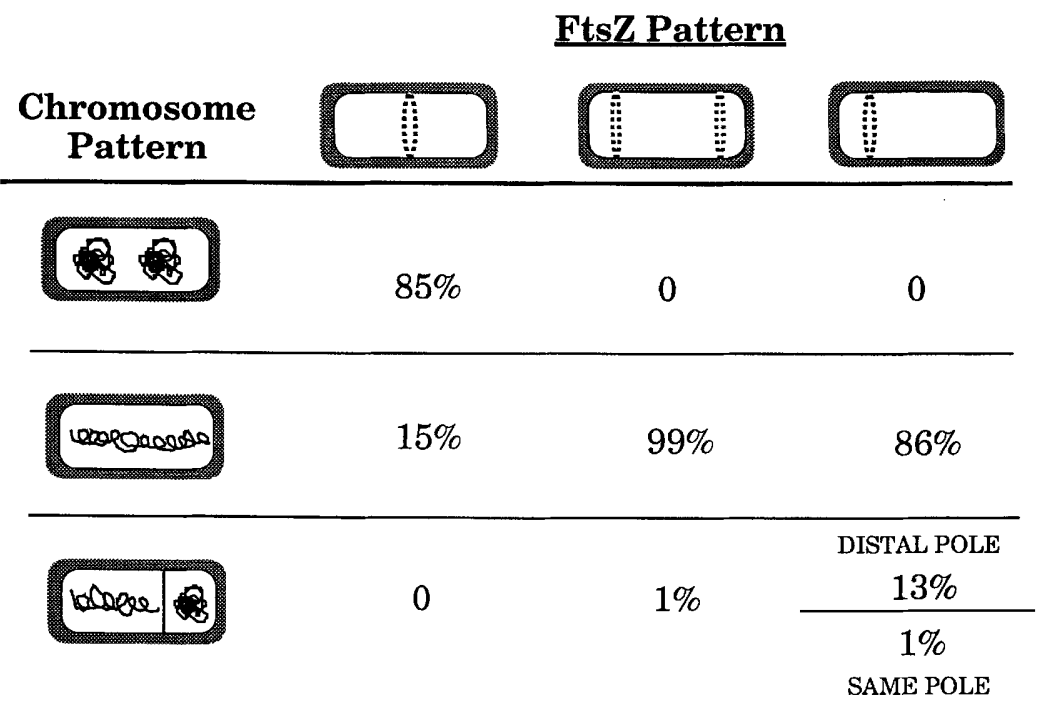

Figure 4. Correlation of the stage of sporulation as determined by nucleoid staining with the pattern of FtsZ localization. The pattern of chromosome staining at the top is indicative of the earliest stage of sporulation, stage 0 . The middle pattern, known as the axial filament, occurs just before or just following formation of the polar septum, during stage I. Finally, the pattern of chromosome staining cartooned at the bottom, in which the forespore nucleoid is fully condensed, is diagnostic of a postdivisional (stage II) sporangium. The percentages of each class of cells are based on 85 sporangia with a medial pattern of FtsZ localization, 161 with a bipolar pattern, and 332 in which FtsZ was localized to a single pole. Note that within the class of sporangia that have FtsZ localization at a single pole and were judged to be at stage II by chromosome staining, the bar of FtsZ was either at the pole distal to the forespore nucleoid or, in a very small number of cases, at the same pole as the nucleoid. inhibition of polar division sites, we would have expected the pattern to be restored in such a double mutant. However, this was not observed. Although bands of FtsZ in the double mutant were positioned at poles as well as in medial locations, in general we only observed one such band per cell length (Fig. 2, part I, V-X). It should be noted that because of the polar septation pattern, min mutant cells tend to filament slightly. We saw no examples of a cell in which FtsZ localized simultaneously to both poles.

\section{Localization of FtsZ in E. coli}

Our success in visualizing FtsZ in $B$. subtilis prompted us to investigate whether IFM could be used to localize FtsZ in logarithmically growing cells of $E$. coli. As has been observed previously by immunoelectron microscopy, the ring of FtsZ becomes progressively smaller as E. coli cells divide (Fig. 2, part II, A-F) (Bi and Lutkenhaus 1991; Lutkenhaus 1993; Erickson 1995). Studies of FtsZ localization in $B$. subtilis using immunoelectron microscopy have shown the protein to be concentrated at the leading edge of the septum, once again suggesting that the FtsZ ring undergoes constriction during septum formation (Wang and Lutkenhaus 1993). In contrast, by IFM, we generally observed only modest variation in the diameter of the FtsZ ring (i.e., the length of the FtsZ bands across the short axis of the cell) from cell to cell during growth and sporulation in B. subtilis (Fig. 2, part I, C and R; P. Levin, unpubl.). Occasionally, cells were observed with only a small band of FtsZ, such as the one at the right-hand end of the filament in Figure 2, part I, R. Also, small quantities of FtsZ were sometimes found to persist between cells that had completed septation (Fig. 2, part I, C). Nevertheless, among undivided cells, less variation in the diameter of the FtsZ band was observed in $B$. subtilis than in E. coli.

\section{Discussion}

The principal contribution of this study is the finding that the assembly sites for the cell division protein FtsZ switch from medial to bipolar positions during the transition from growth to sporulation (Fig. 2, part I, A-F). This result was unexpected because the sporulation septum only forms at one pole in wild-type cells and FtsZ ring formation has generally been thought to be the limiting step in cell division (Ward and Lutkenhaus 1985; Bi and Lutkenhaus 1990). The bipolar pattern of FtsZ localization that we have observed implies that division is initiated, although not completed, at both polar positions simultaneously. Our results are consistent with the electron microscopy studies of Ryter (1964), who noted the presence of "cloisons" or constrictions in the cell wall at both poles of a predivisional sporangium and at the pole distal to the septum in postdivisional sporangia. Ryter speculated that division begins at both poles of the cell but is inhibited at an early stage at one pole, thereby limiting septum formation to the other pole (Ryter 1964). The cloisons that Ryter observed may result from a preliminary invagination of cell wall and membrane caused by FtsZ ring formation. Structures similar to the cloisons have been observed in strains of $E$. coli carrying mutations in the cell division gene fts $A$, and we hypothesize that septation in these mutants is inhibited at a stage subsequent to FtsZ ring assembly (Cook and Rothfield 1994).

The bipolar pattern of FtsZ assembly mirrors the recently reported pattern of localization of the sporulation protein SpoIIE (Arigoni et al. 1995). SpoIIE is an integral membrane protein that is not required for polar division, although the sporulation septum is aberrantly thick in a spoIIE mutant (Piggot and Coote 1976; Illing and Errington 1991; Margolis et al. 1991; F. Arigoni, pers. comm.). Similar to FtsZ, early in sporulation SpoIIE localizes at positions near the cell poles that appear to 
coincide with future division sites. However, in contrast to FtsZ, SpoIIE becomes concentrated at the sporulation septum and disappears from the distal pole (Arigoni et al. 1995). On the basis of the existence of minicell mutants, we and others have speculated that rod-shaped bacteria have marks in their cell envelopes near the cell poles that serve as sites for assembly of the division machinery (Adler et al. 1967; de Boer et al. 1989; Beall and Lutkenhaus 1991; Levin and Losick 1995). Normally, in growing cells, these polar marks are suppressed by MinC and MinD, thus preventing asymmetric septation. During sporulation, however, the polar marks become available for septum formation. The fact that SpoIIE and FtsZ localize in a bipolar manner during sporulation reinforces the idea that such polar marks exist. The nature of the polar marks is unknown, and it is not understood how the polar sites are recognized by FtsZ or SpoIIE. R.G. Wake (pers. comm.) has suggested that the curvature of the peptidoglycan alone at the cell poles may be the cell envelope feature that governs the site of asymmetric septation. Alternatively, marks akin to bud scars in yeast (Chant 1994) left from previous divisions (Burdett 1980) could define sites for polar division. An intriguing question is whether localization of SpoIIE is dependent on FtsZ or whether SpoIIE is capable of recognizing the polar marks independently. [Conversely, we know that polar FtsZ localization is not dependent on SpoIIE both from direct examination (data not shown) and by the fact that spoIIE mutants are not blocked in polar septation [Errington 1993)].

Following an initial bipolar pattern of localization, FtsZ disappears from the pole at which the sporulation septum forms but persists at the distal pole until just shortly after complete segregation of the forespore nucleoid and activation of $\sigma^{\mathrm{F}}$ (Figs. 2, part I, G-I, and 3). The persistence of the distal ring of FtsZ up until the time of $\sigma^{F}$ activation may provide an explanation for the capacity of disporic mutants to form a second polar septum. Disporic mutant cells form one septum first, and then, $\sim 20$ min later (Lewis et al. 1994b), a second septum at the distal pole. The delay in formation of the second septum suggests that division is initiated at both poles simultaneously but that conceivably the machinery required for septation is limiting and only one septum can be formed at a time. The existence of disporic mutants and our present results suggest that the inactivation of the second potential division site in wild-type cells occurs at a step in cytokinesis subsequent to formation of the FtsZ ring. Curiously, in disporic mutants, following segregation of the chromosome into the second polar forespore compartment, the remaining FtsZ protein was found to be localized as a somewhat diffuse mass between the two forespore nucleoids (Fig. 2, part I, J-L).

An important finding of this study is that the switch in FtsZ localization from the medial to bipolar pattern is governed by the sporulation transcription factor Spo0A. A medial pattern of FtsZ localization was maintained for several hours during sporulation in a strain carrying a spoOA null mutation (Fig. 2, part I, P-R). Moreover, the production of an activated form of Spo0A (Sad67) (Ireton et al. 1993) in growing cells switched the assembly site of FtsZ from medial to polar positions (Fig. 2, part I, S-U) and induced the formation of polar septa (Fig. 5A,B). These findings indicate that SpoOA turns on the expression of one or more as yet unidentified genes whose products are sufficient to switch the position of FtsZ assembly.

Interestingly, our results show that $\sigma^{\mathrm{H}}$ is not required for the switch in FtsZ localization even though spooH mutant cells are blocked prior to polar septation (Fig. 2, part I, M-O). Thus, $\sigma^{\mathrm{H}}$ governs a step in septum formation subsequent to assembly of the FtsZ ring. The $\sigma^{\mathrm{H}}$ factor could direct the transcription of cell division genes that mediate septum formation. Alternatively, $\sigma^{\mathrm{H}}$ could control septum formation indirectly by regulating the production of SpoOA, because it is known that $\sigma^{\mathrm{H}}$ stimulates spoOA transcription from a sporulation-specific promoter upstream of the gene. Perhaps a higher level of Spo0A is required for asymmetric cell division than for the switch in FtsZ localization. We favor the former possibility (i.e., that $\sigma^{\mathrm{H}}$ is required for transcription of cell division genes) because artificial production of the Sad67 form of Spo0A during sporulation did not bypass the requirement for $\sigma^{\mathrm{H}}$ for polar septation. In contrast, when the active form of SpoOA was produced during growth, presumably under conditions of relatively high cell division gene expression from vegetative promoters, $\sigma^{\mathrm{H}}$ was not required for the formation of polar septa. Finally, the bipolar pattern of FtsZ localization seen in a spoOH mu-
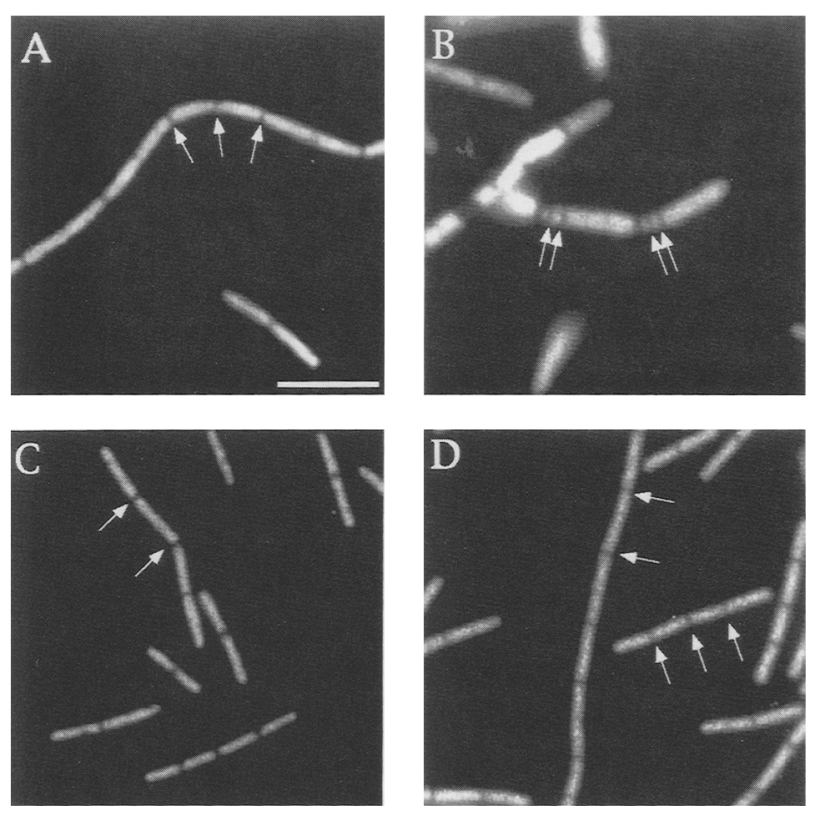

Figure 5. Expression of sad67 during vegetative growth results in the formation of polar septa. All cells have been stained for septa with PI. $(A, B)$ Cells containing $P_{\text {spac }}$-sad67 (SIK31) in the absence $(A)$ and presence $(B)$ of IPTG. $(C, D)$ A congenic strain containing $P_{\text {spac }}-$ SpoOA (SIK167) in the absence $(C)$ and presence $(D)$ of IPTG. The arrows indicate the position of septa. Bar, $5 \mu \mathrm{m}$. 
tant is further evidence that FtsZ localization is not the limiting factor for septation. Rather, polar septation is governed by a $\sigma^{\mathrm{H}}$-controlled step in cytokinesis subsequent to FtsZ ring assembly.

Three further inferences about cell division in vegetative cells can be drawn from this study.

First, the observation that almost every vegetative cell contains two nucleoids and a distinct ring of FtsZ is a strong indication that nucleoid segregation and FtsZ ring formation must occur early in the cell cycle. We therefore infer that DNA replication is completed, and chromosomes segregate into two distinct nucleoids very shortly after birth of the new cell. Additionally, our results suggest that FtsZ ring assembly can be a very early event in the cell cycle under our growth conditions, evidently preceding cytokinesis by a substantial length of time.

Second, some of our findings on the localization of FtsZ in growing B. subtilis cells may not conform with the view that constriction of the FtsZ ring is the driving force behind septum formation. Previous immunoelectron microscopy studies of growing E. coli and B. subtilis cells (Bi and Lutkenhaus 1991; Lutkenhaus 1993; Wang and Lutkenhaus 1993) showed that FtsZ forms a ring at the leading edge of the septum that constricts as cytokinesis progresses. In addition, the results of our own localization of FtsZ in growing $E$. coli cells using IFM showed a wide range of FtsZ band diameters, consistent with the idea that the ring of Fts $Z$ constricts as septation progresses (Fig. 2, part II, A-F). In contrast, our IFM study of growing wild-type and sporulating cells of $B$. subtilis revealed only moderate variation in the diameter of the FtsZ ring from cell to cell (Fig. 2, part $\mathrm{I}, \mathrm{C}$ and $\mathrm{R}$; $\mathrm{P}$. Levin, unpubl.), although an occasional cell was seen having only a very short band of FtsZ. We have no satisfactory explanation for the difference between the results obtained in $B$. subtilis by the high-resolution but low-sensitivity method of immunoelectron microscopy and our present IFM findings. Nonetheless, if our impression that the diameter of the FtsZ ring is more uniform in $B$. subtilis than in $E$. coli is correct, then our findings could have the following implications for the mechanics of septum formation. Gram-positive bacteria divide by building a straight cross wall that separates the two daughter cells. In contrast, Gram-negative bacteria divide by constricting the entire cell envclope at the site of cytokinesis (Koch 1990, Fig. 2, cf. part I, C, with part II, F). Therefore, it is possible that the constriction of the FtsZ ring observed in $E$. coli is solcly a consequence of invagination of the cell envelope rather than inward growth of the septum. In this view FtsZ forms a scaffold upon which the septum is formed both in B. subtilis and E. coli, but septum formation need not be coupled to, or driven by, constriction of the FtsZ ring.

Third, the bipolar pattern that we obscrved in sporulating cells is in contrast to the single ring of FtsZ that we observed in the spoOA minD double mutant (Fig. 2, part $\mathrm{I}, \mathrm{V}-\mathrm{X}$ ) and that has been observed previously in $E$. coli min mutants ( $\mathrm{Bi}$ and Lutkenhaus 1993). The fact that FtsZ assembly is limited to only a single position in min mutants, although theoretically all three sites are available, suggests that under nonsporulation conditions, there is a mechanism that serves to sequester Fts $Z$ to a single division site for cach round of the cell cycle.

In summary, we have shown that FtsZ localizes in a bipolar pattern in sporulating cells and that the switch from a medial to bipolar pattern of localization during the transition from growth to sporulation is controlled by the activated form of the SpoOA transcription factor. We propose the following model for the switch from medial to asymmetric division (Fig. 6). During vegetative growth, FtsZ localizes to the medial site in anticipation of binary fission. This medial pattern of localization is maintained under the control of the products of the $\mathrm{min}$ genes, which inhibit septation at the two poles of the cell but leave the middle site accessible to FtsZ. However, during sporulation, Spo0A $\sim \mathrm{P}$ stimulates the expression of a gene (or genes) whose product inhibits FtsZ ring formation at the medial site and/or activates polymerization at the polar sites, thereby preventing binary fission. Under these conditions, the polar sites become available for FtsZ ring assembly and asymmetric septation. A key challenge now will be to identify the proposed target of SpoOA P that governs the switch in FtsZ localization.

\section{Materials and methods}

\section{Bacterial strains}

The $B$. subtilis strains used were all congenic derivatives of the prototrophic wild-type strain PY79 (Youngman et al. 1984), except where noted. The following sporulation mutant strains were used: RL56 (spo0HAHindIII; laboratory stock); RL891 [spoOADerm; (Margolis et al. 1993); RL1061 [spoIIGBAerm;

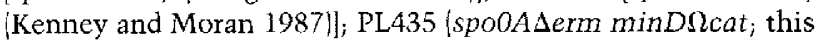
study); SIK31, congenic with JH642 (Perego et al. 1988) [amy$E:: P_{\text {spoc }}$-sad67 spo0Aderm; (Ireton et al. 19931); SIK167, congenic with JH642 (Perego et al. 1988) [amyE::P spac - spoOA spo0A $\Delta e r m$; (Ireton et al. 1993)|. For immunfluorescence experiments involving $E$. coli, we used strain TGl (Sambrook et al. 1989).

\section{General methods}

Luria broth $\{\mathrm{LB} \mid$ medium (Sambrook et al. 1989) was used for the growth of $E$. coli and B. subtilis. Sporulation was induced by resuspension method (Nicholson and Setlow 1990) or by nutrient exhaustion in Difco sporulation (DS) medium (Schaeffer et al. 1965 ; Sandman et al. 1988).

Competent cells were prepared and transformed by the method described in Dubnau and Davidoff-Abelson (1971) with the modification that cells were resuspended in a $1: 2$ dilution of $T$ base with $2 \mathrm{mM}$ EGTA just prior to transformation instead of SpII-EGTA medium (Cutting and Vander Horn 1990). The concentration of antibiotics used for selection on LB agar was spectinomycin at $100 \mu \mathrm{g} / \mathrm{ml}$, chloramphenicol at $5 \mu \mathrm{g} / \mathrm{ml}$, and lincomycin at $25 \mu \mathrm{g}$ plus erythromycin at $1 \mu \mathrm{g} / \mathrm{ml}$ for macrolidelincosamide-streptogramin B (MLS) resistance.

A final concentration of $1 \mathrm{mM}$ IPTG (isopropyl-thio- $\beta$-D-galactosidel was used for induction of the $P_{\text {spac }}-s p o 0 A$ and $P_{\text {spac }}-$ sad67 constructs in both DS and LB media. 
Figure 6. A model for the mechanisms governing septal site selection during vegetative growth and sporulation. Vegetative growth (top half) requires the Min proteins for efficient binary fission. These proteins function together to inhibit septation at the cell poles leaving only the medial site available for cell division (de Boer et al. 1989). In the absence of the Min proteins, all three sites are available for FtsZ ring formation and septation can occur at polar sites resulting in the formation of anucleate minicells. In contrast, during sporulation bottom half|, the activated transcription factor SpoOA $\sim \mathrm{P}$, inhibits division at the medial site, leaving both poles available for FtsZ ring formation. A second transcription factor, $\sigma^{\mathrm{H}}$, is required for polar septation but not for site selection.

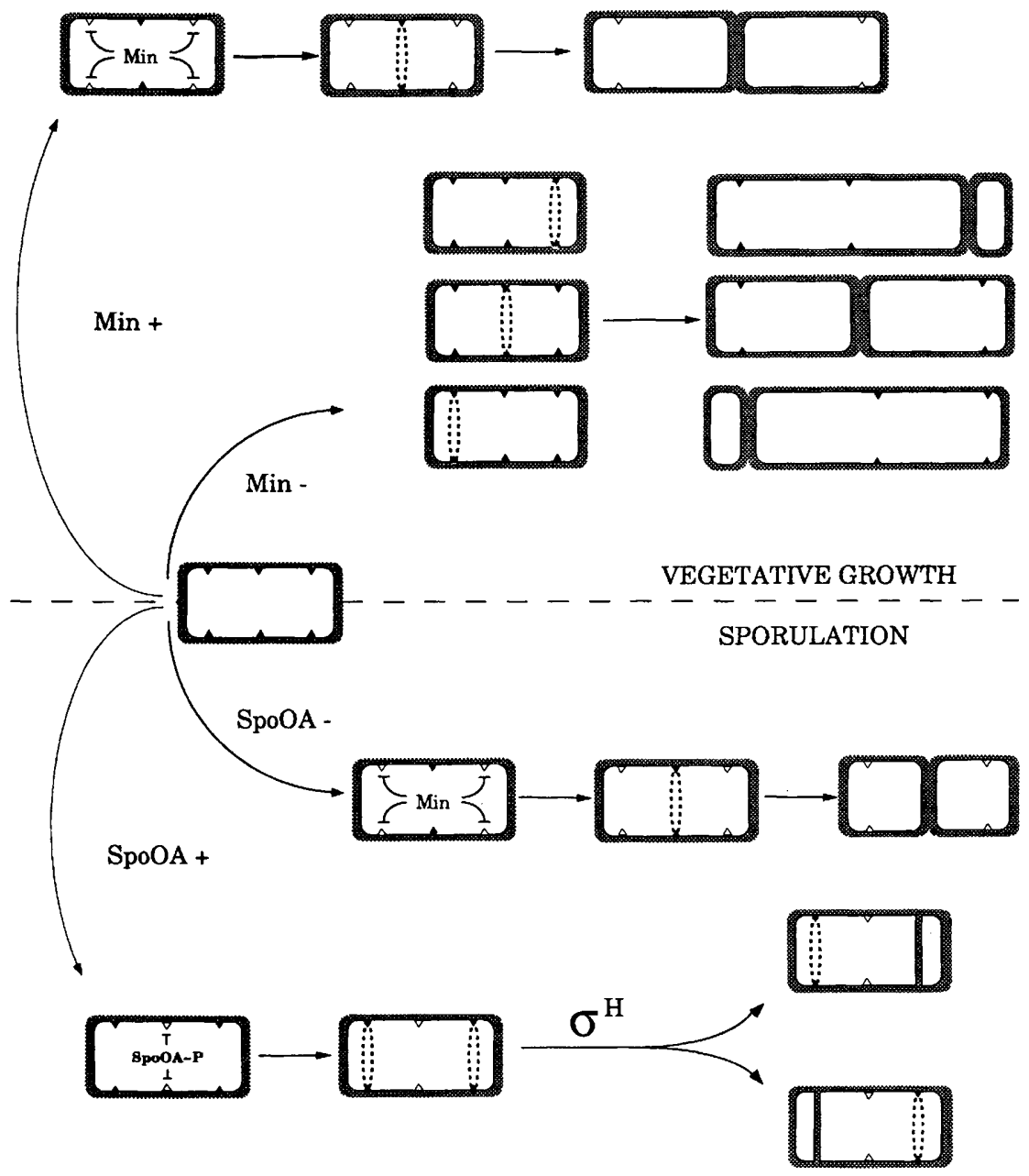

Chromosomal DNA was prepared as described/Cutting and Vander Horn 1990).

\section{Immunofluorescence procedures}

Immunofluorescence was performed as described (Harry et al. 1995; Pogliano et al. 1995) with the following modifications. Cells were sampled from growth or sporulation media and fixed in $30 \mathrm{~mm} \mathrm{NaPO}{ }_{4}$ buffer ( $\mathrm{pH} 7.5$ ) with a final concentration of $2.5 \%(\mathrm{vol} / \mathrm{vol})$ paraformaldehyde, $0.015 \%$ or $0.03 \%$ gluteraldehyde $(\mathrm{vol} / \mathrm{vol})$, for $15 \mathrm{~min}$ at room temperature and $30 \mathrm{~min}$ on ice prior to being washed in phosphate-buffered saline (PBS). The methanol and acetone steps were omitted prior to immunostaining.

$B$. subtilis cells prepared for IFM were incubated overnight at $4^{\circ} \mathrm{C}$ in affinity-purified rabbit antibody raised against $B$. subtilis FtsZ. Two batches of affinity-purified antisera were used. One batch, purified as described (Wang and Lutkenhaus 1993), was the gift of J. Lutkenhaus and was used at a 1:50 dilution. The second batch, used at a dilution of 1:5000, was affinity purified by P. Levin as described (Pringle et al. 1991; Salamitou et al. 1994) from whole rabbit sera (the generous gift of J. Lutkenhaus). Staining of $E$. coli cells was performed using whole rabbit sera directed against $E$. coli FtsZ (also the gift of J. Lutkenhaus) at a $1: 1000$ dilution. All dilutions were done in $2 \%$ BSA PBS solution (wt/vol).
Microscopy and photomicrography were performed as described (Harry et al. 1995; Pogliano et al. 1995). Images were copied from either color $35-\mathrm{mm}$ slides or $35-\mathrm{mm}$ black-andwhite negative film using a Nikon Coolscan slide scanner and processed using Adobe Photoshop on a Macintosh PowerPC 9500 .

\section{PI staining method for visualizing septa}

We devised the following method for visualizing septa, which relies on the nucleic acid stain PI. Although PI is capable of binding both DNA and RNA, in cells that have been incubated with a lysozyme solution, only DNA is stained with PI (Pogliano et al. 1995). However, we found that the cytoplasms of untreated cells stain efficiently with PI. We speculate that the lack of RNA staining in lysozyme-treated cells is attributable to small amounts of contaminating ribonuclease activity in our lysozyme solutions. The efficient cytoplasmic staining of untreated cells with PI allowed us to visualize septa as unstained bands between brightly stained cellular compartments.

Cells were fixed from growth or sporulation media in $2.5 \%$ (vol/vol) paraformaldehyde, $0.03 \%$ gluteraldehyde (vol/vol), and $30 \mathrm{mM} \mathrm{NaPO}{ }_{4}$ buffer $(\mathrm{pH} 7.5)$ at $4^{\circ} \mathrm{C}$. No PBS washes were performed. Untreated 10- $\mu$ l samples of fixed cells were adhered to glass slides that had been treated with $0.1 \%$ (wt/vol) of polyL-lysine (Sigma). After $2 \mathrm{~min}$, the samples were aspirated and 
the slides allowed to air-dry completely. A PI solution (PI, Molecular Probes|, at a final concentration of $0.02 \mu \mathrm{g} / \mathrm{ml}$ in $2 \%$ BSA (wt/vol), was applied to the dry samples and allowed to stand for 5-10 min at room temperature in the dark. The slides were then washed 10 times in PBS and mounted in Slow Fade in a PBS-glycerol solution (Molecular Probes) before fluorescence microscopy. Slides were stored at $-20^{\circ} \mathrm{C}$

\section{Acknowledgments}

We are grateful to Joe Lutkenhaus for the generous gift of antibodies raised against the FtsZ protein and to Alan Grossman for providing strains and valuable advice. We also thank Kit Pogliano and Fabrizio Arigoni for helpful discussions, Robert Pruitt for assistance with image processing, and Joe McCormick, Joe Lutkenhaus, Larry Rothfield, Jeff Errington, Patrick Piggot, and Patrick Stragier for insightful comments on the manuscript. This work was supported by National Institutes of Health grant GM18568 to R.L.

The publication costs of this article were defrayed in part by payment of page charges. This article must therefore be hereby marked "advertisement" in accordance with 18 USC section 1734 solely to indicate this fact.

\section{References}

Adler, H.I., W.D. Fisher, A. Cohen, and A.H. Hardigree. 1967. Miniature Escherichia coli cells deficient in DNA. Proc. Nat. Acad. Sci. 57: 321-326.

Arigoni, F., K. Pogliano, C.D. Webb, P. Stragier, and R. Losick. 1995. Localization of protein implicated in establishment of cell type to sites of asymmetric division. Science 270: 637640.

Beall, B. and J. Lutkenhaus. 1991. FtsZ in Bacillus subtilis is required for vegetative septation and for asymmetric septation during sporulation. Genes \& Dev. 5: 447-455.

1992. Impaired cell division and sporulation of a Bacil. lus subtilis strain with the ftsA gene deleted. I. Bacteriol. 174: 2398-2403.

Beall, B., M. Lowe, and J. Lutkenhaus. 1988. Cloning and characterization of Bacillus subtilis homologs of Escherichia coli cell division genes $f t s Z$ and $f t s A$. I. Bacteriol. 170: 48554864.

Bi, E. and J. Lutkenhaus. 1990. FtsZ regulates frequency of cell division in Escherichia coli. J. Bacteriol. 172: 2765-2768.

. 1991. FtsZ ring structure associated with division in Escherichia coli. Nature 354: 161-164.

-1993. Cell division inhibitors SulA and MinCD prevent formation of the FtsZ ring. I. Bacteriol. 175: 1118-1125.

Burdett, I.D.J. 1980. Quantitative studies of rod-coccus morphogenesis in a temperature-sensitive $\mathrm{rod}^{-}$mutant of Bacillus subtilis. I. Gen. Microbiol. 121: 93-103.

Chant, J. 1994. Cell polarity in yeast. Trends Genet. 10: 328333.

Cook, W.R. and L.I. Rothfield. 1994. Development of the celldivision site in FtsA ${ }^{-}$filaments. Mol. Microbiol. 14: 497503.

Cutting, S.M. and P.B. Vander Horn. 1990. Genetic analysis. In Molecular biological methods for Bacillus (ed. C.R. Harwood and S.M. Cutting), pp. 27-74. John Wiley, Chichester, U.K.

de Boer, P.A.J., R.E. Crossley, and L.I. Rothfield. 1989. A division inhibitor and a topological specificity factor coded for by the minicell locus determine proper placement of the division septum. Cell 56: 641-649.
1992. Roles of MinC and MinD in the site-specific septation block mediated by the MinCDE system of Escherichia coli. J. Bacteriol. 174: 63-70.

Dubnau, D. and R. Davidoff-Abelson. 1971. Fate of transforming DNA following uptake by competent Bacillus subtilis. I. Mol. Biol. 56: 209-221.

Dunn, G. and J. Mandelstam. 1977. Cell polarity in Bacillus subtilis: Effect of growth conditions on spore postions in sister cells. I. Gen. Microbiol. 103: 201-205.

Dunn, G., D.M. Torgersen, and J. Mandelstam. 1976. Order of expression of genes affecting septum location during sporulation of Bacillus subtilis. J. Bacteriol. 125: 776-779.

Erickson, H.P. 1995. FtsZ, a prokaryotic homolog of tubulin. Cell 80: $367-370$.

Errington, J. 1993. Bacillus subtilis sporulation: Regulation of gene expression and control of morphogenesis. Microbiol. Rev. 57: 1-33.

Gholamhoseinian, A., Z. Shen, and P. Piggot. 1992. Regulation of the cell division gene ftsA during sporulation of Bacillus subtilis. I. Bacteriol. 174: 4647-4656.

Gonzy-Tréboul, G., C. Karamzyn-Campelli, and P. Stragier. 1992. Developmental regulation of transcription of the $B a$ cillus subtilis ftsAZ operon. J. Mol. Biol. 224: 967-979.

Grossman, A.D. 1991. Integration of developmental signals and the initiation of sporulation in B. subtilis. Cell 65: 5-8.

Harry, E.J., K. Pogliano, and R. Losick. 1995. Use of immunofluorescence to visualize cell-specific gene expression during sporulation in Bacillus subtilis. I. Bacteriol. 177: 33863393.

Hitchins, A.D. 1975. Polarized relationship of bacterial spore loci to the "old" and "new" ends of sporangia. I. Bacteriol. 121: 518-523.

- 1976. Patterns of spore location in pairs of Bacillus cereus sporangia. J. Bacteriol. 125: 366-368.

Hoch, J.A. 1993. spoO genes, the phosphorelay, and the initiation of sporulation. In Bacillus subtilis and other Gram-positive bacteria (ed. A.l. Sonenshein, J.A. Hoch, and R. Losick), pp. 747-755. American Society for Microbiology, Washington, D.C.

Horvitz, R. and I. Herskowitz. 1992. Mechanisms of asymmetric cell division: Two Bs or not two Bs, that is the question. Cell. 68: 237-255.

Illing, N. and J. Errington. 1991. Roles of $\sigma^{\mathrm{E}}$ and $\sigma^{\mathrm{F}}$ in prespore engulfment. $J$. Bacteriol. 173: 3159-3169.

Ireton, K., D.Z. Rudner, K.J. Siranosian, and A.D. Grossman. 1993. Integration of multiple developmental signals in $\mathrm{Ba}$ cillus subtilis through the Spo0A transcription factor. Genes \& Dev. 7: 283-294.

Kenney, T.J. and C.P. Moran Jr. 1987. Organization and regulation of an operon that encodes a sporulation-essential sigma factor in Bacillus subtilis. J. Bacteriol. 169: 3329-3339.

Kirk, M.M., A. Ransick, S.E. McRae, and D.L. Kirk. 1993. The relationship between cell size and cell fate in Volvox carteri. I. Cell Biol. 123: 191-208.

Koch, A. 1990. Growth and form of the bacterial cell wall. Am. Sci. 78: 327-341.

Labie, C., F. Bouche, and J.-P. Bouche. 1990. Minicell-forming mutants of Escherichia coli: Suppression of both DicB- and MinD-dependent division inhibition by inactivation of the min C gene product. J. Bacteriol. 172: 5852-5855.

Lee, S. and C.W. Price. 1993. The minCD locus of Bacillus subtilis lacks the minE determinant that provides topological specificity to cell division. Mol. Microbiol. 7: 601-610.

Levin, P.A. and R. Losick. 1994. Characterization of a cell division gene from Bacillus subtilis that is required for vegetative and sporulation septum formation. $/$. Bacteriol. 
176: $1451-1459$.

. 1995. Generating specialized cell types by asymmetric division in Bacillus subtilis. Sem. Dev. Biol. 6: 335-345.

Levin, P.A., P. Margolis, P. Setlow, R. Losick, and D. Sun. 1992. Identification of Bacillus subtilis genes for septum placement and shape determination. J. Bacteriol. 174: 6717-6728.

Lewis, P.J., C.E. Nwoguh, M.R. Barer, C.J. Harwood, and J. Errington. 1994a. Use of digitized video microscopy with a fluorogenic enzyme substrate to demonstrate cell- and compartment-specific gene expression in Salmonella enteritidis and Bacillus subtilis. Mol. Microbiol. 13: 655-662.

Lewis, P.J., S.R. Partridge, and J. Errington. 1994b. $\sigma$ factors, asymmetry and the determination of cell fate in Bacillus subtilis. Proc. Natl. Acad. Sci. 91: 3849-3853.

Losick, R. and P. Youngman. 1984. Endospore formation in $\mathrm{Ba}$ cillus. In Microbial development (ed. R. Losick and L. Shapiro), pp. 63-88. Cold Spring Harbor Laboratory, Cold Spring Harbor, NY.

Losick, R., P. Youngman, and P.J. Piggot. 1986. Genetics of endospore formation in Bacillus subtilis. Annu. Rev. Genet. 20: 625-669.

Lutkenhaus, J. 1993. FtsZ ring in bacterial cytokinesis. Mol. Microbiol. 9: 403-409.

Margolin, W., J.C. Corbo, and S.R. Long. 1991. Cloning and characterization of a Rhizobum meliloti homolog of the Escherichia coli cell division gene ftsZ. I. Bacteriol. 173: $5822-5830$.

Margolis, P., A. Driks, and R. Losick. 1991. Establishment of cell type by compartmentalized activation of a transcription factor. Science 254: 562-565.

- 1993. Sporulation gene spoIIB from Bacillus subtilis. I. Bacteriol. 175: 528-540.

McCormick, J.R., E.P. Su, A. Driks, and R. Losick. 1994. Growth and viability of Streptomyces coelicolor mutant for the cell division gene fts $Z$. Mol. Microbiol. 14: 243-254.

Nicholson, W.L. and P. Setlow. 1990. Sporulation, germination and outgrowth. In Molecular biological methods for Bacillus (ed. C.R. Harwood and S.M. Cutting), pp. 391-450. John Wiley, Chichester, UK.

Perego, M., G.B. Spiegelman, and J.A. Hoch. 1988. Structure of the gene for the transition state regulator $a b r B$ : Regulator synthesis is controlled by the spoOA sporulation gene in $\mathrm{Ba}$ cillus subtilis. Mol. Microbiol. 2: 689-699.

Piggot, P.J. and J.G. Coote. 1976. Genetic aspects of bacterial endospore formation. Bacteriol. Rev. 40: 908-962.

Pogliano, K., E. Harry, and R. Losick.1995. Visualization of the subcellular location of sporulation proteins in Bacillus subtilis using immunofluorescence microscopy. Mol. Microbiol. 18: 459-470.

Pringle, J.R., E.E.M. Adams, D.G. Drubin, and B.K. Haarer. 1991. Immunofluorescence methods for yeast. Methods Enzymol. 194: 565-602.

Ryter, A. 1964. Etude morphologique de la sporulation de $B a$ cillus subtilis. Ann. Inst. Pasteur. 108: 40-60.

Salamitou, S., M. Lemaire, T. Fujino, H. Ohayon, P. Gounon, P. Béguin, and J.-P. Aubert. 1994. Subcellular localization of Clostridium thermocellum ORF3p, a protein carrying a receptor for the docking sequence borne by the catalytic components of the cellulosome. J. Bacteriol. 176: 2828-2834.

Sambrook, J., E.F. Fritsch, and T. Maniatis. 1989. Molecular cloning: A laboratory manual. Cold Spring Harbor Laboratory Press, Cold Spring Harbor, NY.

Sandman, K., L. Kroos, S. Cutting, P. Youngman, and R. Losick. 1988. Identification of the promoter for a spore coat protein gene in Bacillus subtilis and studies on the regulation of its induction at a late stage of sporulation. J. Mol. Biol.
200: $461-473$.

Schaeffer, P., J. Millet, and J. Aubert. 1965. Catabolite repression of bacterial sporulation. Proc. Natl. Acad. Sci. 54: 704-711.

Setlow, B., N. Magill, P. Febbroriello, L. Nakhimovsky, D.E. Koppel, and P. Setlow. 1991. Condensation of the forespore nucleoid early in sporulation of Bacillus species. J. Bacteriol. 173: 6270-6278.

Stragier, P. 1989. Temporal and spatial control of gene expression during sporulation: from facts to speculations. In Regulation of procaryotic development (ed. I. Smith, R.A. Slepecky, and P. Setlow), pp. 243-254. American Society for Microbiology, Washington, D.C.

Varley, A.W. and G.C. Stewart. 1992. The divIVB region of the Bacillus subtilis chromosome encodes homologues of Escherichia coli septum placement (MinCD) and cell shape (MreBCD| determinants. I. Bacteriol. 174: 6729-6742.

Wang, X. and J. Lutkenhaus. 1993. The FtsZ protein of Bacillus subtilis is localized at the division site and has GTPase activity that is dependent upon FtsZ concentration. Mol. Microbiol. 9: 435-442.

Ward, J.E. Jr. and J. Lutkenhaus. 1985. Overproduction of FtsZ induces minicell formation in E. coli. Cell 42: 941-949.

Wu, L.J., P.J. Lewis, R. Allmansberger, P.M. Hauser, and J. Errington. 1995. A conjugation-like mechanism for prespore chromosome partitioning during sporulation in Bacillus subtilis. Genes \& Dev. 9: 1316-1326.

Yi, Q.M. and J. Lutkenhaus. 1985. The nucleotide sequence of the essential cell division gene $f t s Z$. Gene 36: 241-247.

Youngman, P.J., J.B. Perkins, and R. Losick. 1984. A novel method for rapid cloning in Escherichia coli of Bacillus subtilis chromosomal DNA adjacent to Tn917 insertions. Mol. Gen. Genet. 195: 424 433. 


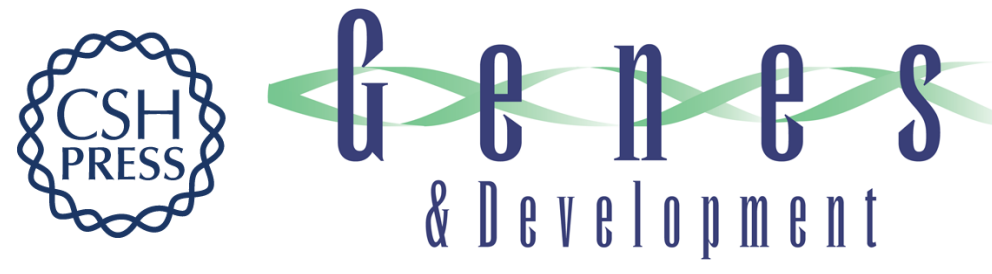

\section{Transcription factor Spo0A switches the localization of the cell division protein FtsZ from a medial to a bipolar pattern in Bacillus subtilis.}

P A Levin and R Losick

Genes Dev. 1996, 10:

Access the most recent version at doi:10.1101/gad.10.4.478

References This article cites 58 articles, 31 of which can be accessed free at: http://genesdev.cshlp.org/content/10/4/478.full.html\#ref-list-1

License

Email Alerting Service

Receive free email alerts when new articles cite this article - sign up in the box at the top right corner of the article or click here.

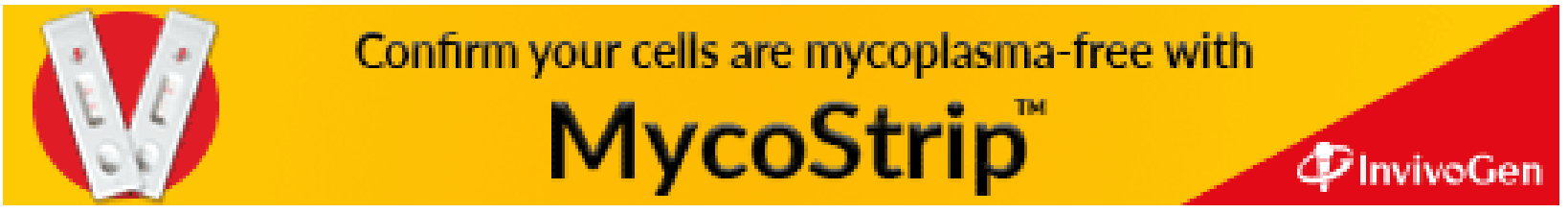

